\title{
PENGARUH PENAMBAHAN GARAM TERHADAP PERUBAHAN KARAKTERISTIK KIMIA DAN PERTUMBUHAN BAKTERI PADA IKAN SEPAT RAWA (Trichogaster trichopterus)
}

\author{
Findya Puspitasari*, Siti Aisyah, Sri Agustiana Wilianti, Kemas Syech Albarah, Rabiatul Adawyah \\ Program Studi Teknologi Hasil Perikanan, Jurusan Pengolahan Hasil Perikanan \\ Fakultas Perikanan dan Kelautan, Universitas Lambung Mangkurat \\ Jalan A. Yani, km 36, Banjarbaru, 70714
}

Diterima: 24 September 2020/Disetujui: 29 April 2021

${ }^{\star}$ Korespondensi: findya.p@gmail.com

Cara sitasi: Puspitasari F, Aisyah S, Agustiana S, Wilianti, Albarah KS, Adawyah R. 2021. Pengaruh penambahan garam pada perubahan karakteristik kimia dan pertumbuhan bakteri pada ikan sepat rawa (Trichogaster trichopterus). Jurnal Pengolahan Hasil Perikanan Indonesia. 24(1): 113-121.

\begin{abstract}
Abstrak
Penelitian ini bertujuan untuk mengetahui pengaruh penggaraman dengan konsentrasi yang berbeda terhadap karakteristik kimia dan pertumbuhan bakteri pada ikan sepat rawa (Trichogaster trichopterus). Perlakuan yang diberikan adalah tanpa penambahan garam (A) sebagai kontrol, garam 5\% (B), garam 10\% (C) dan garam 15\% (D). Analisis kadar air menggunakan metode pengeringan, analisis kadar protein menggunakan metode Kjeldahl, analisis asam amino menggunakan high performance liquid chromatography (HPLC) dan analisis pertumbuhan mikroba menggunakan metode angka lempeng total (ALT). Perlakuan terbaik adalah perlakuan D penambahan garam dengan konsentrasi 15\% menghasilkan kadar air ikan sepat rawa sebesar 61,35\%, kadar protein 31,61\%, dan ALT 5,87 log10 CFU/mL. Profil asam amino esensial yang tertinggi pada perlakuan B yaitu lisina sebesar 2,20\% dan asam amino non esensial yang tertinggi pada perlakuan B yaitu asam glutamat $4,34 \%$.
\end{abstract}

Kata kunci: ALT, asam amino, garam, kadar air, kadar protein

\section{The Effect of Salt Addition on Chemical Characteristics of and Bacterial Growth on Three Spot Gourami (Trichogaster trichopterus)}

\begin{abstract}
This study aimed to determine the effect of addition of different salt concentrations on chemical characteristics and bacterial growth of Three Spot Gourami (Trichogaster trichopterus). The treatments given were no addition of salt (A) as a control, $5 \%$ salt (B), $10 \%$ salt (C) and $15 \%$ salt (D). The moisture was measured using the drying method, while protein content was analysed using the Kjeldahl method. Amino acids content was determined using the high performance liquid chromatography (HPLC) method and the microbial growth was observed using the total plate count (TPC) method. The best treatment was treatment $\mathrm{D}$ with the addition of salt with a concentration of $15 \%$ resulting in water content of three spot gourami $61.35 \%$, protein content $31.61 \%$, and TPC $5.87 \log 10 \mathrm{CFU} / \mathrm{mL}$. The highest profile of essential amino acids in treatment B was lysine at $2.20 \%$ and the highest non-essential amino acids in treatment B was glutamic acid at $4.34 \%$.
\end{abstract}

Keywords: amino acids, protein content, salt content, Three Spot Gourami, TPC, water content 


\section{PENDAHULUAN}

Ikan sepat rawa merupakan jenis ikan konsumsi yang banyak terdapat di Provinsi Kalimantan Selatan, karena Kalimantan Selatan memiliki kawasan rawa yang luas. Masyarakat Kalimantan Selatan selama ini melakukan pengawetan ikan sepat rawa dengan cara penggaraman karena prosesnya yang mudah dan sederhana. Ikan adalah bahan pangan yang mudah mengalami kebusukan karena memiliki kadar air dan protein yang tinggi serta memiliki $\mathrm{pH}$ yang mendekati netral, untuk mengawetkan ikan masyarakat umumnya melakukan penggaraman. Penggaraman ikan adalah proses pengawetan tradisional yang sudah sejak lama dilakukan masyarakat karena prosesnya yang sederhana dan mudah. Ikan setelah digarami akan menjadi awet, karena garam bersifat higroskopis sehingga dapat menarik air keluar dari tubuh ikan sehingga kerja mikroorganisme pembusuk pada ikan akan terhambat (Adawyah 2016). Beberapa penelitian mengenai pengawetan ikan dengan metode penggaraman telah banyak dilakukan diantaranya adalah penggaraman pada: ikan gabus (Ophiocephalus striatus) (Rochima 2005); ikan kembung perempuan (Rastrelliger brachysoma) (Juharni 2013); ikan bandeng (Chanos chanos sp) (Tumbelaka et al. 2013); ikan kawalinya (Selar laptolepis) (Tahitu 2014); ikan bandeng (Chanos chanos sp) (Patang dan Yunarti 2014); ikan kembung (Rastrelliger neglectus) (Thariq 2014); ikan layang (Bahmid et al. 2019).

Tujuan dari penelitian ini adalah untuk melihat bagaimana pengaruh dari proses penggaraman terhadap karakteristik kimia (kadar air, kadar protein, asam amino) dan pertumbuhan bakteri total (Total Plate Count) pada ikan sepat rawa (Trichogaster trichopterus). Kegunaan dari penelitian ini adalah sebagai informasi bagi masyarakat mengenai pengaruh pengawetan dengan metode penggaraman terhadap karakteristik kimia (kadar air, kadar protein, profil asam amino) dan pertumbuhan bakteri pada ikan sepat rawa sehingga dapat menjadikannya sebagai bahan literatur dalam suatu penelitian atau keperluan lainnya.

\section{BAHAN DAN METODE}

Bahan baku utama digunakan pada penelitian yaitu ikan sepat rawa dan garam. Bahan yang digunakan dalam analisis kadar protein adalah selenium, $\mathrm{H}_{2} \mathrm{SO}_{4}$ pekat, akuades, asam borat $\left(\mathrm{H}_{3} \mathrm{BO}_{3}\right) 2 \%, \mathrm{NaOH}$ $40 \%, \mathrm{HCl} 0,1 \mathrm{~N}$, dan indikator bromokresol hijau-metil merah. Bahan untuk analisis asam amino adalah $\mathrm{HCl} 6 \mathrm{~N}$, ortoftalaldehida (OPA), $\mathrm{HCl}$ 0,01 N, metanol, merkaptoetanol, brij-30 30\%, kertas milipore bufer kalium borat, dan larutan asam amino standar 0,5 $\mu \mathrm{mol} / \mathrm{mL}$. Bahan yang digunakan dalam analisis pertumbuhan mikroba dengan metode TPC adalah plate count agar (PCA), buffered peptone water (BPW), dan akuades.

Peralatan untuk proses penggaraman yaitu timbangan, toples dan pisau. Peralatan untuk analisis kadar air adalah cawan porselin, desikator, tang penjepit, oven, dan timbangan analitik. Peralatan uji kadar protein terdiri dari neraca analitik, beaker glass, lemari asam, pipet ukur, labu kjeldahl, buret dan statif, erlenmeyer, distilator, labu ukur, dan alat destruksi. Analisis asam amino dengan menggunakan seperangkat alat high performance liquid chromatography (HPLC), syringe, oven, dan evaporator. Peralatan analisis pertumbuhan bakteri total: cawan petri, mikropipet, inkubator, gelas ukur, autoklaf, hot plate dan stirrer, timbangan digital, spatula, beaker glass, tabung reaksi, rak tabung reaksi, bunsen dan erlenmeyer.

\section{Proses penggaraman ikan sepat rawa}

Ikan sepat rawa segar dilakukan penyiangan dengan membuang bagian organ dalam dan insang, kemudian dilakukan pencucian dengan air bersih. Ikan yang sudah dilakukan penyiangan dan pencucian kemudian ditimbang dan diberi larutan garam sesuai dengan perlakuan yaitu perendaman selama 24 jam dalam larutan garam dengan konsentrasi larutan garam untuk perlakuan B $5 \%$, perlakuan C $10 \%$, dan perlakuan D $15 \%$. Perlakuan A sebagai kontrol merupakan ikan segar tanpa proses penggaraman.

\section{Prosedur analisis}

Penelitian eksprimen dengan metode rancangan acak lengkap (RAL) menggunakan 
empat perlakuan yaitu penggaraman menggunakan garam dengan konsentrasi larutan garam yang berbeda yaitu $0 \%$, $5 \%, \quad 10 \%$ dan 15\%. Analisis kadar air menggunakan metode pengeringan (AOAC 1995), metode untuk analisis kadar protein (AOAC 2005) dan metode high performance liquid chromatography (HPLC) digunakan untuk analisis asam amino (AOAC 2005), dan pengujian pertumbuhan bakteri berdasarkan SNI 01-2332-3-2006 menggunakan metode angka lempeng total (ALT).

Data hasil analisis yang diperoleh dilakukan pengujian secara statistik menggunakan analisis sidik ragam untuk mengetahui apakah perlakuan penggaraman memberikan pengaruh. Apabila perlakuan penggaraman memberikan pengaruh nyata maka dilakukan uji lanjut Duncan untuk mengetahui pengaruh di antara perlakuan pada taraf kepercayaan 95\%.

\section{HASIL DAN PEMBAHASAN Kadar Air Ikan Sepat Rawa}

Hasil pengujian kadar air menggunakan metode pengeringan disajikan pada Figure 1. Grafik yang disajikan pada Figure 1 menunjukkan hasil pengujian kadar air ikan yang paling tinggi didapatkan pada perlakuan B (perendaman dalam larutan garam dengan konsentrasi 5\% selama 24 jam) diikuti perlakuan A (ikan segar tanpa perlakuan perendaman dalam larutan garam) $65,27 \%$, perlakuan C (perendaman dalam larurtan garam dengan konsentarasi 10\% selama 24 jam) 62,24\%, dan yang memiliki kadar air paling rendah adalah perlakuan D (perendaman dalam larurtan garam dengan konsentarasi 15\% selama 24 jam 61,35\%). Data hasil analisis yang diperoleh kemudian dilakukan pengujian secara statistik menggunakan analisis sidik ragam untuk mengetahui apakah perlakuan penggaraman memberikan pengaruh terhadap kadar air ikan sepat rawa. Hasil analisis menunjukkan bahwa perlakuan penggaraman dengan konsentrasi berbeda berpengaruh sangat nyata terhadap kadar air ikan sepat rawa. Hasil analisis menunjukkan adanya pengaruh yang nyata sehingga dilanjutkan pengujian perbedaan antara perlakuan. Dari hasil uji lanjut Duncan didapatkan bahwa antara perlakuan A dan C tidak ada pengaruh nyata sedangkan antara perlakuan A-B, perlakuan A-D, perlakuan B-C, perlakuan B-D, dan perlakuan C-D menunjukkan adanya perbedaan yang nyata.

Penurunan kadar air sejalan dengan semakin meningkatnya kadar garam yang digunakan namun jika dilihat pada Figure 1 kadar air ikan sepat pada perlakuan B mengalami peningkatan dibandingkan perlakuan A karena pada perlakuan A tidak dilakukan proses perendaman (ikan segar), sedangkan perlakuan B dilakukan perendaman selama 24 jam dengan konsentrasi garam yang rendah hanya $5 \%$. Kadar air ikan pada perlakuan C dan D kembali mengalami penurunan karena konsentrasi garam yang digunakan semakin meningkat. Menurut Adawyah (2016), selama proses penggaraman terjadi penetrasi garam ke dalam tubuh ikan sehingga cairan dari tubuh ikan keluar.

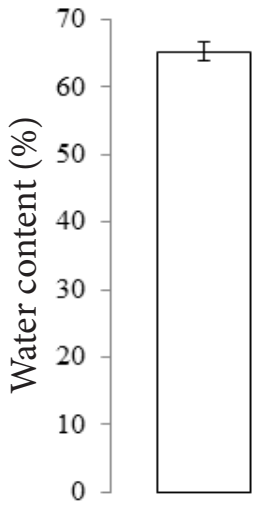

(A)

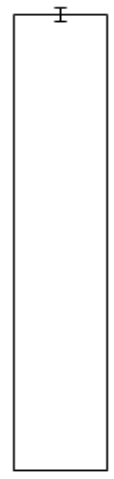

(B)

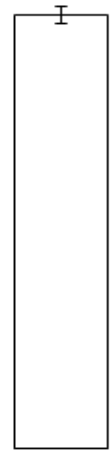

(C)

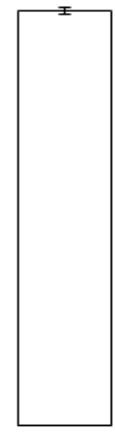

(D)

Figure 1 Three spot gourami water content treated with differences salt concentrations; $A=0 \%$ salt; $B=5 \%$ salt; $C=10 \%$ salt; $D=15 \%$ salt. 
Semakin tinggi konsentrasi garam yang digunakan selama penggaraman maka kadar air ikan semakin menurun (Rahmani et al. 2007; Paparang 2013; Akbardiansyah et al. 2018). Terjadi penurunan kadar air dari ikan segar selama proses penggaraman. Peningkatan penurunan kadar air sejalan dengan jumlah garam yang diberikan, semakin tigggi jumlah garam yang digunakan maka penurunan kadar air semakin tinggi (Hafez et al. 2019).

\section{Kadar Protein Ikan Sepat Rawa}

Hasil analisis kadar protein dengan perlakuan konsentrasi penggaraman yang berbeda pada ikan sepat rawa disajikan pada Figure 2.

Grafik yang disajikan pada Figure 2 menunjukkan hasil kadar protein dari ikan sepat rawa dengan perlakuan penggaraman menggunakan konsentrasi berbeda. Kadar protein ikan sepat rawa paling tinggi didapatkan pada perlakuan D (perendaman dalam larutan garam dengan konsentarasi 15\% selama 24 jam) diikuti perlakuan C (perendaman dalam larutan garam dengan konsentrasi 10\% selama 24 jam) 65,27\%, perlakuan B (perendaman dalam larutan garam dengan konsentrasi 5\% selama 24 jam) $23,12 \%$, dan yang memiliki kadar protein paling rendah adalah perlakuan A (ikan segar tanpa perlakuan perendaman dalam larutan garam) $17,71 \%$. Data hasil analisis yang diperoleh kemudian dilakukan pengujian secara statistik menggunakan analisis sidik ragam untuk mengetahui apakah perlakuan

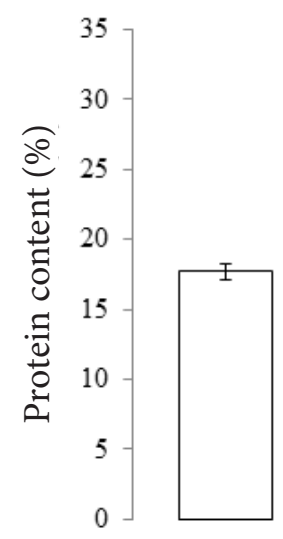

(A)

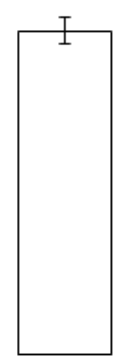

(B) penggaraman dengan konsentrasi yang berbeda memberikan pengaruh terhadap kadar protein ikan sepat rawa, hasil analisis sidik ragam menunjukkan bahwa perlakuan penggaraman dengan konsentrasi berbeda berpengaruh sangat nyata terhadap kadar protein ikan sepat rawa. Hasil menunjukkan berpengaruh nyata sehingga dilanjutkan pengujian untuk mengetahui pengaruh antara perlakuan. Dari hasil uji lanjut duncan didapatkan bahwa antara semua perlakuan menunjukan adanya perbedaan yang nyata.

Kadar protein ikan sepat rawa setelah dilakukan perlakuan penggaraman mengalami peningkatan, peningkatan kadar perotein sejalan dengan peningkatan jumlah garam yang diberikan semakin tinggi kadar garam maka semakin tinggi kadar protein ikan sepat rawa. Hasil ini menunjukkan kesesuaian dengan hasil kadar air yang juga mengalami penurunan dengan semakin meningkatnya kadar garam yang digunakan dalam proses penggaraman. Menurut Adawyah (2007), apabila kadar air menurun maka kandungan protein meningkat. Dalam penelitian yang dilakukan pada ikan van (Alburnus tarichi) menunjukan bahwa kandungan protein pada ikan yang dilakukan penggaraman lebih tinggi dibandingkan dengan ikan segar (Kılınççeker dan Küçüköner 2003; Binici dan Kaya 2018).

\section{Asam Amino Ikan Sepat Rawa}

Hasil pengujian profil asam amino ikan sepat rawa dengan HPLC disajikan pada Figure 3. Kandungan asam amino pada masing-masing perlakuan dari yang

Figure 1 Three spot gourami protein content treated with differences salt concentrations; $A=0 \%$ salt; $B=5 \%$ salt; $C=10 \%$ salt; $D=15 \%$ salt. 
paling rendah ke yang paling tinggi, untuk perlakuan A kandungan asam amino esensial terdiri dari asam amino histidina $0,54 \%$ yang paling rendah diikuti oleh metionina $0,63 \%$, tirosina $0,77 \%$, treonina $0,99 \%$, isoleusina $1,05 \%$, fenilalanina $1,07 \%$, valina $1,11 \%$, leusina $1,96 \%$ dan yang paling tinggi asam amino lisina 2,2\%. Perlakuan B kandungan asam amino yang paling rendah adalah hisitidina $0,43 \%$ diikuti oleh metionina $0,47 \%$, tirosina $0,47 \%$, treonina $0,54 \%$, valina $0,84 \%$, fenilalanina $0,87 \%$, leusina $1,48 \%$, lisina $1,55 \%$ dan kandungan asam amino yang paling tinggi adalah isoleusina $1,88 \%$. Perlakuan C kandungan asam amino yang paling rendah adalah histidina $0,43 \%$ diikuti oleh metionina $0,47 \%$, tirosina $0,54 \%$, treonina $0,54 \%$, valina $0,84 \%$, fenilalanina $0,87 \%$, leusina $1,48 \%$, lisina $1,55 \%$ dan kandungan yang paling tinggi adalah isoleusina $1,88 \%$. Perlakuan C kandungan asama amino yang paling rendah adalah metionina $0,33 \%$, dikuti oleh histidina $0,34 \%$, tirosina $0,39 \%$, treonina $0,57 \%$, isoleusina $0,6 \%$, valina $0,63 \%$, fenilalanina $0,64 \%$, leusina $1,1 \%$ dan kandungan paling tinggi adalah lisina $1,17 \%$.

Kandungan asam amino non esensial ikan sepat rawa untuk masing-masing perlakuan adalah sebagai berikut. Perlakuan A kandungan asam amino paling rendah adalah serina $0,71 \%$ diikuti oleh arginina $1,15 \%$, alanina $1,43 \%$, glisina $1,73 \%$, asam aspartat $1,9 \%$ dan kandungan asam amino paling tinggi adalah asam glutamat 3,25\%. Perlakuan B kandungan asam amino paling rendah adalah serina $0,93 \%$ diikuti oleh arginina $1,44 \%$, alanina $1,86 \%$, glisina $2,11 \%$, asam aspartat 2,48\% dan kandungan asam amino yang paling tinggi adalah asam glutamat $4,34 \%$. Perlakuan C kandungan asam amino yang paling rendah adalah serina $0,73 \%$ diikuti oleh arginina $1,26 \%$, alanina $1,45 \%$, asam aspartat $1,88 \%$, glisina $1,93 \%$, dan kandungan asam amino yang paling tinggi adalah asam glutamat 3,24\%. Perlakuan D kandungan asam amino yang paling rendah adalah serina $0,54 \%$ diikuti oleh alanina 1,04\%, arginina $1,11 \%$, glisina $1,29 \%$, asam aspartat $1,43 \%$ dan yang paling tinggi asam glutamat 2,36\%.

Hasil penelitian menunjukkan bahwa profil asam amino ikan sepat rawa mengalami perubahan setelah dilakukan penggaraman (Figure 3). Untuk asam amino esensial yang tertinggi pada sepat rawa adalah lisina diikuti leusina dan isoleusina. Asam-asam amino ini memiliki peranan yang cukup penting bagi

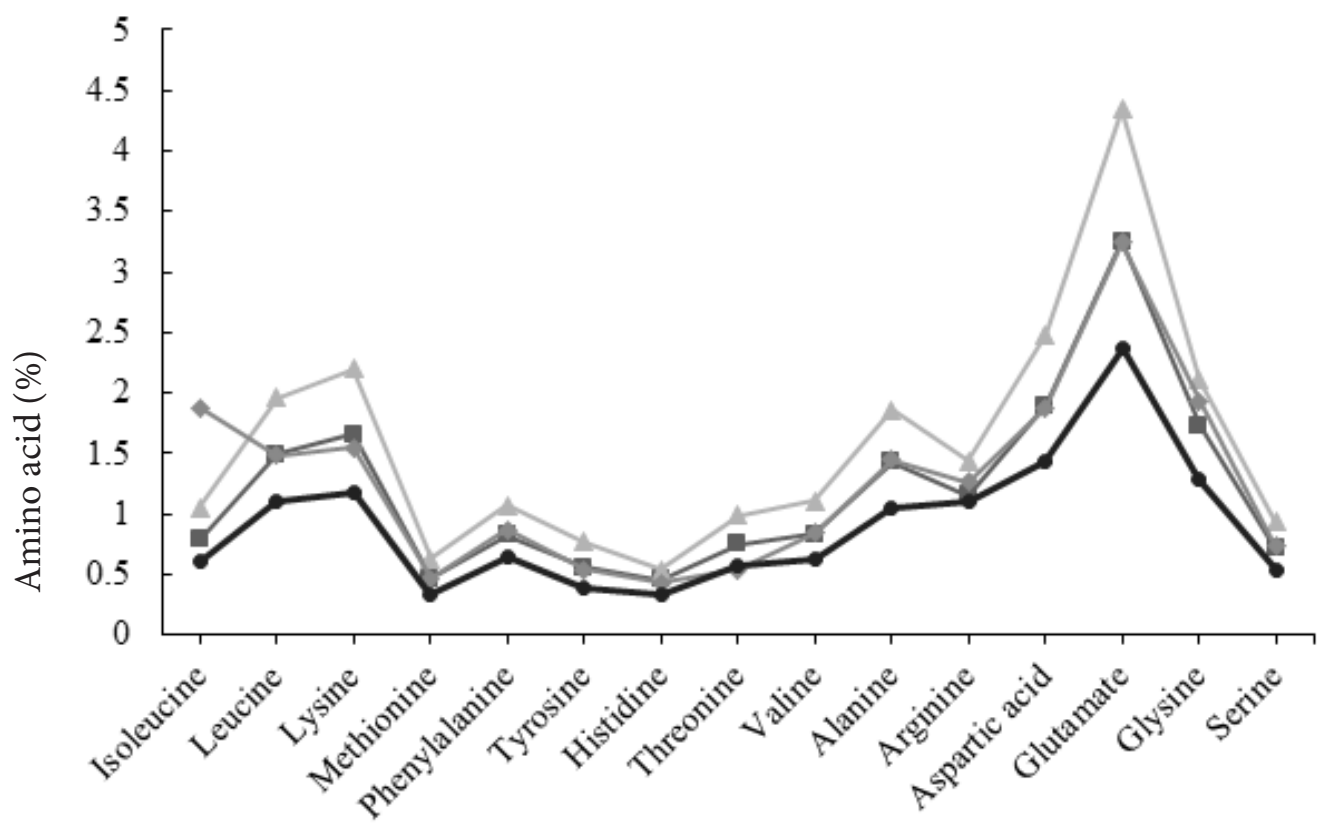

Figure 3 Amino acid profile of three spot gourami with different salt concentrations; $\longrightarrow-0 \%$ salt; $\longrightarrow 5 \%$ salt; $\longrightarrow 10 \%$ salt; $\longrightarrow 15 \%$ salt. 
tubuh. Lisina berfungsi untuk membantu mengangkut lemak ke seluruh sel tubuh untuk dibakar menjadi energi serta dapat menormalisasi atau menurunkan tekanan darah pada penderita hipertensi (Ama et al. 2017), dapat mengurangi kecemasan dengan cara memblokir reseptor respons stres (Smriga et al. 2004; Smriga et al. 2007). Lisina dapat membantu tubuh mempertahankan kalsium (Civitelli et al. 1992; Shimomura et al. 2014), meningkatkan penyerapan kalsium di usus dan membantu ginjal untuk mempertahankannya (Civitelli et al. 1989; Sinha dan Goel 2009).

Leusina adalah asam amino yang digunakan oleh tubuh terutama untuk membangun otot dan menyediakan energi, bermanfaat untuk mengurangi kelelahan dan aktivitas setelah latihan yang lama atau intens (Fouré dan Bendahan 2017). Leusina dapat merangsang sintesis protein di otot rangka (Viana et al. 2019). Isoleusin penting dalam fungsi fisiologis seluruh tubuh, seperti pertumbuhan, kekebalan, metabolisme protein, metabolisme asam lemak, dan transportasi glukosa, dapat meningkatkan sistem imun, termasuk organ imun, sel dan zat reaktif (Changsong et al. 2019). Jenis asam amino non esensial paling tinggi yang terdapat pada ikan sepat rawa sebelum dan sesudah dilakukan penggaraman adalah asam glutamat. Glutamat dan glutamin merupakan sebagian besar dari total asam amino dalam ikan baik dalam bentuk bebas maupun terikat dengan protein (Li et al. 2020).
Peningkatan kadar garam pada ikan sepat rawa pada penelitian ini menyebabkan kadar air mengalami penurunan sedangkan kadar protein ikan sepat rawa meningkat. Grafik kombinasi perbandingan kadar garam, air, protein dan asam amino ikan sepat rawa disajikan pada Figure 4.

Penelitian menunjukkan peningkatan jumlah garam yang digunakan pada proses penggaraman mengakibatkan kadar air ikan menurun, karena garam bersifat higroskopis yaitu mampu mengikat air sehingga dapat menurunkan kadar air. Penurunan kadar air mengakibatkan kandungan protein meningkat (Adawyah 2016). Kandungan asam amino ikan sepat rawa setelah diberikan penggaraman 5\% mengalami peningkatan, akan tetapi penggunaan garam dengan konsentrasi yang lebih tinggi menyebabkan semakin rendahnya asam amino ikan sepat rawa. Hal ini karena penggunaan garam dengan konsentrasi garam yang lebih tinggi menyebabkan enzim yang bekerja untuk memecah protein menjadi asam amino aktivitasnya terhambat dan terjadi penurunan kelarutan protein sehingga kandungan asam amino pada ikan menurun. Pemberian konsentrasi garam yang berbeda dapat memengaruhi tinggi rendahnya kandungan asam amino yang terdapat pada ikan sepat rawa.

\section{Nilai TPC Ikan Sepat Rawa}

Nilai TPC ikan sepat rawa yang didapatkan pada penelitian ini disajikan pada Figure 5.

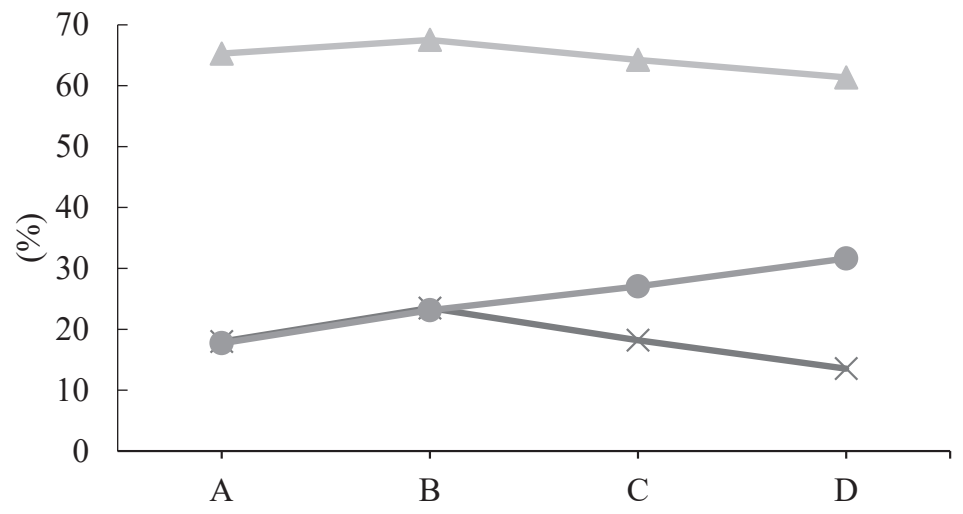

Figure 4 Combination of amino acid total, water content and protein content of three spot gourami with different salt concentrations; $\mathrm{A}=0 \%$ salt; $\mathrm{B}=5 \%$ salt; $\mathrm{C}=10 \%$ salt; $\mathrm{D}=15 \%$ salt; $\longleftarrow$. amino acid total; $\longrightarrow$ water content; $\longrightarrow$ protein content 


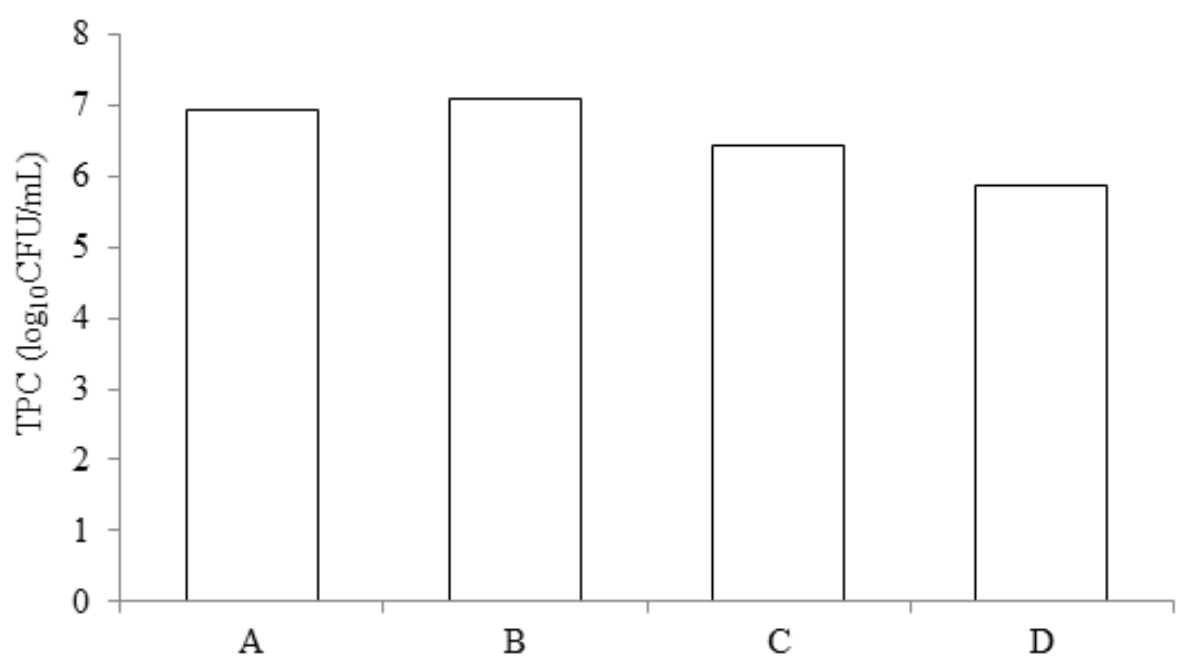

Figure 5 TPC of three spot gourami with differences salt concentrations; $A=0 \%$ salt; $B=5 \%$ salt; $\mathrm{C}=10 \%$ salt; $\mathrm{D}=15 \%$ salt

Berdasarkan hasil pengamatan semakin tinggi konsentrasi garam yang diberikan semakin rendah jumlah koloni bakteri pada ikan sepat rawa. Figure 5 menunjukkan bahwa nilai $\log$ TPC ikan sepat rawa pada perlakuan A lebih rendah dari perlakuan B. Hal ini karena sebagian besar bakteri halofobik masih dapat bertahan hidup, bakteri halofobik memiliki toleransi rendah terhadap garam, tetapi golongan ini pada konsentrasi garam dibawah 6\% masih mampu untuk bertahan hidup. Perlakuan C dan perlakuan D jumlah koloni bakteri mengalami penurunan seiring dengan peningkatan konsentrasi garam yang digunakan. Garam berfungsi menarik air dari tubuh ikan sepat rawa sehingga dapat menyeleksi atau mengurangi jumlah bakteri yang berkembang biak.

\section{KESIMPULAN}

Penambahan garam dengan konsentrasi yang berbeda memberikan pengaruh terhadap kadar air, protein, asam amino dan TPC ikan sepat rawa. Perlakuan terbaik adalah perlakuan $\mathrm{D}$ penambahan garam dengan konsentrasi 15\% menghasilkan kadar air ikan sepat rawa sebesar 61,35\%, kadar protein 34,07\%, dan TPC 5,87 $\log _{10}$ CFU/mL. Profil asam amino esensial yang tertinggi pada perlakuan B yaitu lisina sebesar $2,20 \%$ dan asam amino non esensial yang tertinggi pada perlakuan B yaitu asam glutamat $4,34 \%$.

\section{DAFTAR PUSTAKA}

Adawyah R. 2016. Pengantar Teknologi Hasil Perikanan. Bumi Aksara. Jakarta.

Akbardiansyah, Desniar, Uju. 2018 Karakteristik ikan asin kambing-kambing (Canthidermis maculata) dengan penggaraman kering. Jurnal Pengolahan Hasil Perikanan Indonesia. 21(2): 345355.

[AOAC] Association of Official Analytical Chemist. 1995. Official Method of Analysis of the Association of Official Analytical of Chemist. Arlington (US): The Association of Official Analytical Chemist, Inc.

[AOAC] Association of Official Analytical Chemist. 2005. Official Method of Analysis of the Association of Official Analytical of Chemist. Virginia (US): The Association of Analytical Chemist, Inc.

[BSN] Badan Standardisasi Nasional. 2006. SNI 01-2323.3-2006. Cara Uji MikrobiologiBagian 3 Penentuan Angka Lempeng Total (ALT) Pada Produk Perikanan. Jakarta (ID): Badan Standardisasi Nasional.

Bahmid J, Lekahena VNJ, dan Titaheluw SS. 2019. Pengaruh konsentrasi larutan garam terhadap karakteristik sensori produk ikan layang asin asap. Jurnal Biosaintek. 1(1): 56-60.

Binici A, Kaya GK. 2018. Effect of brine and dry salting methods on the physicochemical and microbial quality of chub (Squalius 
cephalus Linnaeus, 1758). Food Science and Technology. 38(1):,66-70.

Changsong G, Xiangbing M, Daiwen C, Bing Y dan Qing Y. 2019. Isoleucine plays an important role for maintaining immune function. Current Protein \& Peptide Science 20: 644.

Civitelli R, Fedde KN, Harter J. 1989. Effect of L-lysine on cytosolic calcium homeostasis in cultured human normal fibroblasts. Calcified Tissue International. 45: 193197.

Civitelli R, Villareal DT, Agnusdei D, Nardi P, Avioli LV, Gennari C. 1992. Dietary L-lysine and calcium metabolism in humans. Nutrition. 8(6): 400.

Fouré A, Bendahan D. 2017. Is branchedchain amino acids supplementation an efficient nutritional strategy to alleviate skeletal muscle damage? a systematic review. Nutrients. 9(10):1047.

Hafez NE, Awad, AM, Ibrahim SM, Mohamed HR, El-Lahamy AA. 2019. Effect of salting process on fish quality. Nutrition and Food Processing. 2(1).

Juharni. 2013. Pengaruh konsentrasi garam dan lama fermentasi terhadap kadar histamin peda ikan kembung perempuan (Rastrelliger neglectus). Agrikan: Jurnal Agribisnis Perikanan. 6(1): 73-80.

Kılınççeker O dan Kuçuköner E. 2003. Determination of some physical, chemical and biochemical changes on salted pearl mullet (Chalcalburnus tarichi). Yuzuncu Yil Üniversitesi Ziraat Fakultesi Tarım Bilimleri Dergisi. 13(1): 55-59.

Li X, Zheng S, Wu G. 2020. Nutrition and metabolism of glutamate and glutamine in fish. Amino Acids. 52: 671-691.

Patang, Yunarti. 2014. Pemberian berbagai dosis garam terhadap kualitas ikan bandeng (Chanos chanos sp) asin kering. Jurnal Galang Tropika. 3(3): 171-178.

Paparang RW. 2013. Studi pengaruh variasi konsentrasi garam terhadap citrarasa peda ikan layang. Media Teknologi Hasil Perikanan. 1(1): 17-20.

Rahmani Y, Erryana M. 2007. Pengaruh metode penggaraman basah terhadap karakteristik produk ikan asin gabus (Ophiocephalus striatus). Jurnal Teknologi
Pertanian. 8(3): 142-152.

Rochima E. 2005. Pengaruh fermentasi garam terhadap karakteristik jambal roti. Buletin Teknologi Hasil Perikanan. 8(2): 46-56.

Sakti H, Lestari S, Supriadi A. 2016. Perubahan mutu ikan gabus (Channa striata) asap selama penyimpanan. Jurnal Teknologi Hasil Perikanan. 5(1): 11-18.

Schweigert BS, HR Kraybill, and DA Greenwood. 2010. Amino acid composition of fresh and cooked beef cuts. Journal Science Food and Nutrition, 56(2): 156-162.

Shimomura A, Matsui I, Hamano T, et al. 2014. Dietary L-lysine prevents arterial calcification in adenine-induced uremic rats. Journal of the American Society of Nephrology. 25(9):1954-1965.

Sinha S, Goel SC. 2009. Effect of amino acids lysine and arginine on fracture healing in rabbits: A radiological and histomorphological analysis. Indian Journal of Orthopaedics. 43(4): 328-334.

Smriga M, Ghosh S, Mouneimne Y, Pellett PL, Scrimshaw NS. 2004. Lysine fortification reduces anxiety and lessens stress in family members in economically weak communities in Northwest Syria. Proceedings of the National Academy of Sciences of the United States of America. 101(22):8285-8.

Smriga M, Ando T, Akutsu M, Furukawa Y, Miwa K, Morinaga Y. 2007. Oral treatment with L-lysine and L-arginine reduces anxiety and basal cortisol levels in healthy humans. BioMed Research International. 28(2):85-90.

Tahitu J. 2014. Pengaruh konsentrasi garam dan waktu perendaman ikan kawalinya (Selar laptolepis) asin kering. Jurnal Biopendix. 1(1): 65-70.

Thariq. 2014. Pengaruh perbedaan konsentrasi garam pada peda ikan kembung (Rastrelliger neglectus) terhadap kandungan asam glutamat pemberi rasa gurih (umami). Jurnal Pengolahan dan Bioteknologi Hasil Perikanan. 3(3): 104111.

Tumbelaka RA, Naiu S, Daili. 2013. Pengaruh konsentrasi garam dan lama penggaraman terhadap nilai hedonik 
ikan bandeng (Chanos chanos sp). Jurnal Ilmiah Perikanan dan Kelautan. 1(1): 4954

Viana LR, Tobar N, Busanello ENB. et al. 2019. Leucine-rich diet induces a shift in tumour metabolism from glycolytic towards oxidative phosphorylation, reducing glucose consumption and metastasis in Walker-256 tumour-bearing rats. Scientific Reports. 9: 15529.

Vuvor F, Mohammed H, Ndanu T, Harrison O. 2017. Effect of lysine supplementation on hypertensive men and women in selected peri-urban community in Ghana. $B M C$ Nutrition. 3: 67. 